\title{
Pembentukan Konsep Diri Remaja Melalui Penanaman Nilai-Nilai Keislaman
}

\author{
Adi Saputra, Yuzarion \\ Universitas Ahmad Dahlan Yogyakarta \\ putra1933b@gmail.com
}

\begin{abstract}
The purpose of the current study is to determine how self-concept forms in adolescents through inculcating Islamic values. Literature study from various sources, including abstracts of scientific writing results, journal reviews published between 2010-2018 and books related to this article, was employed as the research method. The self-concept is all our perceptions about our self-aspects, such as physical aspect, social aspect, and psychological aspect, which are based on our experiences and interactions with other people. The conclusion of this study is that family support plays a very significant role in the formation self-concepts in adolescents, where families that establish good parent-child communication can nurture positive self-concepts in their children. The self-concept develops gradually and is influenced by the closest circle like the people in the family and the views of the adolescents about themselves. In the process of forming the self-concept in adolescents, it is indispensable to instill Islamic values. With the inculcation of Islamic values, positive self-concepts can be formed in the adolescents' minds. The results of this study indicate that adolescents who are implanted with Islamic values tend to have positive self-concepts, compared to adolescents whose self-concepts tend to be negative due to the lack Islamic values inculcation during the self-concept formation progress.
\end{abstract}

Keywords: Self-Concept, Adolescent, Islamic Values.

\begin{abstract}
Abstrak
Tujuan dari penelitian ini adalah untuk mengetahui bagaimana konsep diri terbentuk pada remaja melalui penanaman nilai-nilai Islami. Studi literatur dari berbagai sumber, antara lain abstrak hasil penulisan ilmiah, resensi jurnal yang diterbitkan antara 2010-2018 dan buku-buku yang terkait dengan artikel ini, digunakan sebagai metode penelitian. Konsep diri adalah semua persepsi kita tentang aspek diri kita, seperti aspek fisik, aspek sosial, dan aspek psikologis, yang didasarkan pada pengalaman dan interaksi kita dengan orang lain. Kesimpulan dari penelitian ini adalah bahwa dukungan keluarga sangat berperan dalam pembentukan konsep diri pada remaja, dimana keluarga yang menjalin komunikasi orang tua-anak yang baik dapat menumbuhkan konsep diri yang positif pada anak-anaknya. Konsep diri berkembang secara bertahap dan dipengaruhi oleh lingkungan terdekat seperti orangorang dalam keluarga dan pandangan remaja tentang dirinya. Dalam proses pembentukan konsep diri pada remaja, sangat diperlukan penanaman nilai-nilai Islami. Dengan penanaman nilai-nilai Islami, konsep diri yang positif dapat terbentuk
\end{abstract}


dalam benak remaja. Hasil penelitian ini menunjukkan bahwa remaja yang ditanamkan nilai-nilai Islam cenderung memiliki konsep diri yang positif, dibandingkan dengan remaja yang konsep dirinya cenderung negatif karena kurangnya penanaman nilai-nilai Islam selama pembentukan konsep diri berlangsung.

Kata Kunci: Konsep Diri, Remaja, Nilai-Nilai Islam.

\section{Pendahuluan}

Masa remaja merupakan masa dimana seseorang memperbaharui identitas dirinya yang sudah ada semenjak dia lahir. Dalam proses tersebut para remaja dihadapkan dengan berbagai tantangan, dimana dalam fase ini remaja mengalami perubahan mulai dari perubahan fisik, social, intelektual, serta emosi mereka. Konsep diri adalah semua persepsi kita terhadap aspek diri yang meliputi aspek fisik, aspek social, dan aspek psikologi, yang didasarkan pada pengalaman dan interaksi kita dengan orang lain (Alex Sobur, 2016). Artinya bahwa pembentukan konsep diri itu sendiri sangat dipengaruhi oleh lingkungan, pengalamanpengalaman interaksi dengan orang lain serta nilai-nilai agama yang dianut oleh individu itu sendiri.

Al Quran juga menjelaskan dalam surat An-Nur ayat 59. Dalam ayat ini dimaksudkan bahwa dalam Islam tidak mengenal remaja namun menyebutnya dengan kata baligh, yaitu ditandai dengan menarche (menstruasi pertama) pada perempuan dan mimpi basah pada laki-laki (Marliana Eka Saputri \& Moordiningsih, 2016). Maksud dari ayat ini adalah bagaimana agama islam mengatur kehidupan para remaja yang di sebut dengan akil baligh yang dalam masa tersebut sudah dikenai kewajiban untuk beribadah kepada Allah SWT. serta menjalankan kehidupan berlandaskan dengan nilai-nilai agama islam.

Nilai-nilai agama merupakan pondasi yang sangat vital untuk seseorang dalam membentuk kepribadian maupun tingkah lakunya. Oleh sebab itu tinggi rendahnya pemahaman dan pengamalan nilai-nilai agama seseorang akan berdampak pada tingkah laku dan kepribadiannya termasuk juga dalam pembentukan konsep diri seseorang.

Fenomena-fenomena akhir ini dimana para orang tua sangat jarang dalam menanamkan nilai-nilai keagaaman mereka hanya menyerahkan penanaman nilainilai keagaaman terhadap sekolah saja. Terkait dengan hal itu peneiliti tertarik untuk meneliti tentang bagaimanakah pembentukan konsep diri remaja melalui penanaman nilai-nilai keislaman. Tujuan dari penelitian ini adalah untuk mengetahui bagaimanakah pembentukan konsep diri remaja melalui penanaman nilai-nilai keislaman. 


\section{Metode Penelitian}

Metode dalam artikel ini adalah studi literatur dari berbagai sumber diantaranya adalah abstrak hasil penulisan ilmiah, ulasan jurnal yang terbit antara tahun 2010-2018 serta buku-buku yang berkaitan dengan artikel ini, yang akan menunjang dalam proses pembuatan artikel.

\section{Hasil dan Pembahasan}

Penelitian ini menemukan bahwa dalam pembentukan konsep diri remaja dengan penanaman nilai-nilai keislaman cenderung memiliki konsep diri yang positive dibandingkan dengan para remaja yang dalam proses pembentukan konsep dirinya tanpa penanaman nilai-nilai keislaman. Nilai keislaman adalah sebagai konsep dan keyakinan yang dijunjung tinggi oleh manusia mengenai beberapa masalah pokok yang berhubungan dengan islam untuk dijadikan pedoman dalam bertingkah laku, baik nilai yang bersumber dari Allah maupun hasil interaksi manusia tanpa bertentangan dengan syariat.

Penanaman nilai-nilai keislaman sangat berpengaruh terhadap hasil dari proses pembentukan konsep diri seorang remaja. Konsep diri seorang remaja akan positiv jika dalam proses pembentukannya di Tanami dengan nilai-nilai keislaman nilai-nilai keislaman yang dimaksud adalah: berbakti terhadap kedua orang tua, sholat lima waktu, berbudi pekerti yang baik, berbicara yang sopan dan lain sebagainya.

Nilai-nilai agama islam memiliki kebenaran yang hakiki. Nilai-nilai keislaman merupakan petunjuk, pedoman dan pendorong bagi manusia dalam memecahkan masalah hidup seperti ilmu agama, ekonomi, politik, social, budaya dan lain sebagainya sehingga terbentuk pola motivasi, tujuan hidup dan perilaku manusia yang menuju kepada keridhaan Allah SWT. oleh karena itu untuk membentuk konsep diri remaja yang positive maka sangatlah perlu penanaman nilai-nilai keislaman, supaya konsep diri dari remaja tersebut berlandaskan pada pokok-pokok nilai-nilai keislaman seperti akidah, syariah, dan akhalak.

Penanaman nilai-nilai agama merupakan suatu bagain dalam pemebentukan konsep diri seorang remaja. Hal tersebut disebabkan karena nilai-nilai agama merupakan landasan bagi seseorang dalam bertingkah laku. Bila dalam proses pembentukan konsep diri remaja dilakukan dengan penanaman nilai-nilai agama maka konsep diri remaja cenderung positif, namun begitupun sebaliknya bila dalam pemebentukan konsep diri remaja tidak ditanamkan nilai-nilai keagamaan maka konsep diri remaja cenderung negative.

Hasil penelitian dari Luthfita dan Eko menyatakan bahwa Pola asuh nenek (grandparenting) pada kedua subjek sama-sama didasarkan pada aspek "kasihan". Dari rasa kasihan tersebut, Nenek lebih memanjakan dan mengabulkan segala keinginan masing-masing subjek sehingga subjek berperilaku ketergantungan dan 
semena-mena dengan Nenek. Pada segi psikologis komunikasi yang membentuk konsep diri subjek, kedua subjek cenderung negatif. Masing-masing subjek, membuat cerminan diri sebagai individu yang "tidak baik" atau pembawa pengaruh buruk karena anak broken home. Artinya bahwa pembentukan konsep diri seorang remaja juga sangat ditentukan oleh lingkunga keluarga (Luthfita dan Eko, 2016).

Sejalan dengan itu hasil penelitian dari Marliana Eka Saputri dan Moordiningsih, menunjukkan Bentuk-bentuk dukungan keluarga Jawa yang beragama Islam dalam pembentukan konsep diri remaja yaitu dukungan dalam bentuk perhatian, motivasi, nasehat, juga fasilitas. Namun kesemuanya yang terpenting adalah keadaan keluarga yang menyenangkan bagi remaja yaitu adanya perhatian dari orang tua untuk selalu berusaha mengetahui keadaan remaja tentang apa yang dirasakan dan yang dihadapi sehingga orang tua senantiasa mengontrol anak remajanya. Pemikiran positif dari orang tua untuk anak remajanya sehingga itu akan membentuk konsep diri yang positif pada remaja (Marliana Eka Saputri dan Moordiningsih, 2016).

Menurut Lisnani Sukaidawati dkk (2016), dalam hasil penelitiannya menyarankan untuk meningkatkan konsep diri ibu sebagai upaya untuk meningkatkan konsep diri remaja. Adapun dimensi-dimensi yang perlu ditingkatkan pada ibu agar dapat meningkatkan perkembangan konsep diri remaja adalah dimensi spiritual, akademik, stabilitas emosi, dan penampilan fisik ibu. Selain remaja itu sendiri orang-orang terdekat dari remaja itu sendiri seperti orang tua, saudara dan sebagainya harus juga memiliki penghayatan terhapa nilai-nilai keagamaan untuk membentuk konsep diri remaja kearah positiv. Kenapa demikian karena dalam proses pembentukan konsep diri remaja orang-orang disekitarnya sangatlah berpengaruh terutama orang tua, bila penanaman nilai-nilai keagamaan sudah diamalkan oleh orang tua maka otomatis anak akan meniru hal tersebut dan berdampak terhadap pembentukan konsep diri anak tersebut.

Penelitian lain juga yang dilakukan oleh (Agus Sofyandi Kahfi, 2016) menunjukkan bahwa kondisi konsep diri individu yang meliputi pemahaman sebagai pribadi yang kuat, sebagai pribadi yang percaya diri dan kompeten serta sebagai pribadi yang berkembang, akan berhubungan dan atau dipengaruhi oleh derajat keberagamaan yang mengandung unsur tata nilai yang dijadikan dasar keyakinan dan pedoman hidup individu, bagaimana ia menjalankan tata nilai tersebut dalam bentuk peribadahan serta bagaimana ia menjadikan tata nilai tersebut sebagai pewarna dan hiasan sikap dan perilakunya.

Hal di atas sejalan dengan prespektif konstruk sosial yang antara lain menyatakan bahwa karakteristik konsep diri dibentuk melalui penanaman nilai moral dan agama oleh orang tua (Mendaglio \& Pyryt, 2002). Sejalan dengan ini, Festinger (Mendaglio \& Pyryt, 2002) menyatakan bahwa setiap orang memiliki keinginan untuk melakukan evaluasi terhadap opini dan kemampuan dirinya secara 
akurat, dan akurasi dari suatu evaluasi sangat membutuhkan kriteria yang dapat dijadikan sarana membandingkan antara self pribadi dengan orang lain dan kriteria yang bisa dijadikan pembanding utamanya adalah agama yang dianut individu.

Hasil penelitian McCullough dan Willough (2009) yang menemukan bahwa keberagamaan atau komitmen beragama Islam akan mempengaruhi beberapa hal. Pertama, tujuan hidup individu terutama pada proses pemilihan tujuan, meningkatkan beberapa tujuan penting yang ditentukan sendiri, mengurangi konflik antar tujuan dan mempengaruhi bagaimana tujuan tersebut diinternalisakinan. Kedua, mendorong adanya monitoring diri, terutama dalam menjadikan ajaran agama, ajaran moral, komunitas agama dan ritual keagamaan sebagai sarana memonitor diri. Ketiga, meningkatkan kekuatan regulasi diri, terutama ketika terlibat dalam komunitas keagamaan dan menjalankan ajaran ritual. Keempat, meningkatkan kemampuan mastery (pengujian terhadap keberhasilan performance yang sesuai harapan).

Dalam prosesnya konsep diri terbentuk tidak dalam kurun waktu yang singkat konsep diri terbentuk karena adanya Interaksi individu dengan orang-orang di sekitarnya. Saat masih kecil, orang penting disekitar kita seperti orang tua dan saudara-saudara kita adalah merupakan factor yang menentukan pembentukan konsep diri kita. Ketika anak memasuki jenjang remaja, maka dengan sendirinya ia akan mengalami hal-hal baru terkait dengan konsep diri mereka. Dalam fase ini remaja masih belum menemukan konsep diri mereka yang sebenarnya mereka masih dalam kebimbangan namun seiring dengan berjalannya waktu dan pengalaman-pengalaman yang di alami oleh remaja maka dengan sendirinya remaja akan memiliki konsep diri yang tetap.

Nilai-nilai pendidikan Islam disetiap perilaku, berarti melahirkan nilai-nilai Islami yang memberi ruang lingkup keagamaan. Nilai disini yang dimaksud adalah nilai yang diajarkan di dasarkan pada ajaran Islam. Maka sejauh mana pemahaman dari seorang guru terhadap ajaran agama Islam, dan sejauh itu pula penggunaan materi yang disampaikan kepada anak didik, dan sejauh itu pula ajaran agama Islam sebagai sumber nilai.

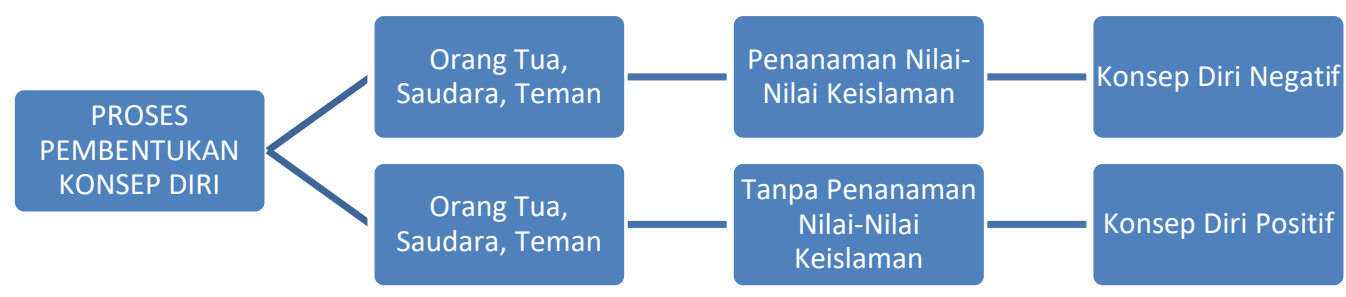

\section{Kesimpulan}

Simpulan dari penelitian ini ialah dukungan keluarga sangat berperan dalam pembentukan konsep diri remaja, dimana keluarga yang menjalin komunikasi secara baik antara orang tua dan anak dapat membentuk konsep diri yang positif 
bagi anak. Konsep diri berkembang secara bertahap dan dipengaruhi oleh orang terdekat yaitu keluarga serta pandangan diri remaja sendiri terhadap dirinya.

Dalam proses pembentukan konsep diri remaja sangat perlu di tanamkan nilai-nilai keislaman, dengan penanaman nilai-nilai keislaman bias terbentuk konsep diri yang positif dari para remaja. Hasil dari penelitian ini menunjukkan bahwa remaja yang dalam proses pembentukan konsep dirinya di tanamkan dengan nilai-nilai keislaman cenderung mempunyai konsep diri yang positif, dibandingkan dengan remaja yang dalam proses pembentukan konsep dirinya tanpa ditanamkan nilai-nilai keislaman cenderung negativ.

Konsep diri yang positif juga terbentuk melalui orang-orang terdekat seperti orang tua, saudara dan masyarakat sekitar, oleh sebab itu orang tua harus bias menjdai contoh para remaja dalam segala hal baik itu cara bertingkah laku, cara berbicara dan lain sebagainya.

\section{Daftar Pustaka}

Agus Sofyandi Kahfi, (2016), Komitmen Beragama Islam, "Konsep Diri” Dan "Regulasi Diri " Para Pengguna Narkoba, Psikologika, 87-104

Alex Sobur. (2016). Psikologi Umum. Bandung: Pustaka Setia.

Al Ahsani, Nasirudin. Kepemimpinan Perempuan Pada Masyarakat dalam Perspektif Sa īd Ramaḍān Al-Būṭī (Telaah Hadis Misoginis). Jurnal AlHikmah, 2020, 18.1: 57-74.

Fauzi, Ahmad. Problematika Dakwah di Tengah Pandemi Covid 19 Mewabah. Jurnal Al-Hikmah, 2020, 18.1: 27-36.

Hadi, H. Sofyan. Manajemen Strategi Dakwah di Era Kontemporer. Jurnal AlHikmah, 2019, 17.1: 79-90.

Ida Windi Wahyuni. (2011). Hubungan Kematangan Beragama Dengan Konsep Diri. Al-Hikmah, 1-9.

Lisnani Sukaidawati, dkk. (2016) Konsep Diri Ibu Dan Remaja Pada Keluarga Cerai Dan Utuh. Jurnal Ilmu keluarga \& Konsumen, 11-20.

Luthfita Cahya Irani \& Eko Pramudya Laksana, (2018), Konsep Diri dan Keterbukaan Diri Remaja Broken Home yang Diasuh Nenek, Jurnal Pendidikan, 685-692.

Marliana Eka Saputri, Moordiningsih. (2016). Pembentukan Konsep Diri Remaja Pada Keluarga Jawa Yang Bergama Islam. Jurnal Ilmiah Psikolog Terapan, 261-268.

McCullough, M. E., \& Willoughby, B. L. B. (2009), Religion, self regulation, and Kontrol diri: Association, Explanation and Implications. Psycological Bulletin, 135 (1), 69-63.

Mendaglio, S., \& Pyryt, M. C. (2002). Self concept: A multi theory perspective. 